\title{
Muzeji od doma: digitalne aktivnosti hrvatskih muzeja tijekom pandemije bolesti COVID-19
}

\author{
Lana Dom šić \\ Veleučilište Baltazar Zaprešić, Hrvatska \\ e-mail: ldomsic@bak.hr
}

\author{
Barbara Franić \\ Veleučilište Baltazar Zaprešić, Hrvatska \\ e-mail:bfranic@bak.hr
}

\author{
Mirna Perić \\ Veleučilište Baltazar Zaprešić, Hrvatska \\ e-mail:pericmirna1@gmail.com
}

SAŽETAK U ožujku 2020. godine vrata hrvatskih muzeja zatvorena su na nekoliko tjedana kako bi se spriječilo širenje bolesti COVID-19. Razdoblje fizičke zatvorenosti dodatno se produžilo za pojedine zagrebačke muzeje teško stradale u potresu. Nakon otvaranja, kao i u mnogim drugim muzejima u Europi i svijetu, fizičke posjete i dalje su smanjene i muzeji bilježe drastičan pad posjetitelja te financijske gubitke. Kao odgovor na trenutnu situaciju, s ciljem nastavka ispunjavanja svoje društvene, kulturne i obrazovne funkcije, muzeji su se okrenuli internetu i društvenim mrežama kao mjestima za dijalog s korisnicima, diseminaciju sadržaja i prezentaciju događanja koja se ne mogu fizički organizirati. Mnogi muzeji posvetili su se stvaranju internetskih resursa poput digitalnih izložbi, virtualnih tura, materijala za e-učenje, internetskih konferencija te se na različite načine i na različitim platformama nastoje povezati sa svojom publikom.

Cilj ovog rada bio je istražiti kako su hrvatski muzeji korištenjem digitalnih medija prilagodili svoje usluge i sadržaje novim uvjetima poslovanja. U radu su analizirane i vrednovane aktivnosti muzeja na mrežnim stranicama i društvenim mrežama u godini dana od početka pandemije. Rezultati ukazuju na kvantitativno kao i kvalitativno bogatu internetsku prisutnost muzeja, koja bi mogla značiti početak nove ere u digitalnoj komunikaciji i diseminaciji baštinskih sadržaja. Istraživanje zaključuje da je digitalizacija aktivnosti muzeja nužna za buduću održivost muzejskih funkcija te potiče daljnja razmišljanja o smjeru digitalnog pristupa kulturi i baštini.

Ključne riječi: virtualni muzeji, digitalizacija, digitalna tehnologija, društvene mreže, COVID-19, pandemija, digitalna transformacija, korisnici. 


\section{Uvod}

U ožujku 2020. godine koronavirus je prisilio većinu muzeja u cijelom svijetu da zatvore vrata. Čak i u rijetkim mjestima gdje se to nije dogodilo ili je zatvaranje trajalo kratko, gotovo su potpuno prestali posjeti muzejima školskih grupa, drastično je smanjen kulturni turizam i dolazak međunarodnih posjetitelja zbog zatvaranja granica, a lokalni posjetitelji ostali su doma iz straha od zatvorenih javnih prostora.

Hrvatski muzeji također su, kao dio mjera protiv širenja bolesti COVID-19, zatvoreni na nekoliko tjedana, a razdoblje fizičke zatvorenosti dodatno se produžilo za pojedine zagrebačke muzeje teško stradale u potresima u ožujku te prosincu 2020. godine. Nakon otvaranja, kao i u mnogim drugim muzejima u Europi i svijetu, fizičke su posjete i dalje smanjene i hrvatski muzeji bilježe drastičan pad posjetitelja te financijske gubitke. Kao odgovor na trenutnu situaciju, s ciljem nastavka ispunjavanja svoje društvene, kulturne i obrazovne funkcije, muzeji su se okrenuli internetu i društvenim mrežama kao mjestima za dijalog s korisnicima, diseminaciju sadržaja i prezentaciju događanja koja se nisu mogla fizički organizirati. Mnogi muzeji posvetili su se stvaranju internetskih resursa poput digitalnih izložbi, virtualnih tura, materijala za e-učenje, internetskih konferencija te se na različite načine i na različitim platformama nastoje povezati sa svojom publikom.

Iako je većina muzeja imala profile na društvenim mrežama i poduzimala digitalne inicijative i prije zatvaranja, njihove aktivnosti u digitalnim medijima značajno su narasle u protekloj godini te su muzeji uvidjeli njihove prednosti u smislu proširivanja publike i novih načina interakcije $s$ korisnicima.

Cilj ovog rada bio je istražiti kako su hrvatski muzeji korištenjem digitalnih medija prilagodili svoje usluge i sadržaje novim uvjetima poslovanja. U radu se analiziraju i vrednuju aktivnosti muzeja na mrežnim stranicama i društvenim mrežama u godini dana od početka pandemije u ožujku 2020. godine. U nastavku rada prikazan je kontekst istraživanja te do sada provedene studije na temu digitalizacije muzejskih sadržaja i funkcija tijekom pandemijske krize u svijetu i u Hrvatskoj. Nakon toga prikazani su rezultati istraživanja koji se odnose na analizu sadržaja mrežnih stranica hrvatskih muzeja, kojom su prikupljeni podaci o tome koliko se digitalna aktivnost muzeja povećala u odnosu na razdoblje prije pandemije, koji su se novi oblici prezentacije i komunikacije muzejskih sadržaja pojavili te kakvu su recepciju imali kod muzejske publike u smislu razine internetskog angažmana koju su proizveli. 


\section{Kontekst istraživanja}

Istraživanja na svjetskoj i europskoj razini o utjecaju koronavirusa na muzeje koja su provele međunarodne organizacije UNESCO, ICOM i NEMO ukazuju na slične rezultate - veliki financijski gubici, pad posjećenosti, otpuštanje muzejskog osoblja te prekid muzejskih programa i projekata.

UNESCO u svom izvještaju Museums around the world in the face of COVID-19 (2020.) navodi da je čak $90 \%$ muzeja u svijetu (više od 85000 institucija) zatvorilo vrata tijekom pandemije, a od toga se njih $10 \%$ više nikada neće otvoriti. Kada se i otvore, muzeji će i dalje osjećati financijske gubitke zbog smanjenih državnih i privatnih sredstava uslijed ekonomske krize, dramatičan pad sponzorstava i donacija, kao i kolapsa međunarodnog turizma zbog posljedica pandemijske krize, koje će potrajati još godinama.

Istraživanje Europske mreže muzejskih organizacija (NEMO), provedeno u studenom 2020. godine među 600 muzeja iz 48 zemalja, pokazalo je da je više od 70\% muzeja i dalje bilo zatvoreno, a od onih koji su otvorili svoja vrata $88 \%$ ih je zabilježilo drastičan pad posjetitelja (NEMO, 2020.). Kada se i otvore, muzeji će i dalje osjećati financijske gubitke zbog smanjenih državnih i privatnih sredstava uslijed ekonomske krize i kolapsa međunarodnog turizma kao posljedica pandemijske krize, koje će potrajati još godinama. Prema NEMO-u, glavni su razlozi smanjenog broja posjetitelja u muzejima unatoč ponovnom otvaranju nakon zatvaranja pad turizma $(73 \%)$, prekid školske godine i posljedični gubitak suradnje s obrazovnim institucijama (64\%) te strah muzejske publike od potencijalnih gužvi (54\%). Izvješće NEMO-a također naglašava snažne negativne financijske utjecaje pandemije na muzeje.

Premda je zatvaranje hrvatskih muzeja trajalo svega mjesec i pol, za razliku od europskih koji su bili zatvoreni i do šest mjeseci, a neki su to i dalje, podaci o padu posjećenosti jednako su dramatični. Prema istraživanju Muzejskog dokumentacijskog centra (MDC), hrvatski su muzeji u 2020. godini zabilježili pad od gotovo četiri milijuna posjetitelja, odnosno za 72\% u odnosu na 2019. godinu (MDC, 2021.a) Činjenica je da se brojni posjetitelji i dalje osjećaju nesigurnima u zatvorenim javnim prostorima, a velik pad posjetitelja uzrokovao je i nedolazak stranih turista te otkazivanje posjeta školskih grupa. Zagrebačke muzeje dodatno je devastirao potres od 22. ožujka, uslijed kojeg je, zbog šteta na zgradama, čak trećina stalnih postava zagrebačkih muzeja ostala duže vrijeme zatvorena, a neki su, poput Hrvatskog povijesnog muzeja, zatvoreni i dalje.

Sve navedeno zahtijevalo je od muzeja hitnu prilagodbu novonastaloj situaciji i odgovor na nova očekivanja i potrebe korisnika. Naime, muzeji i baštinske ustanove trebale bi igrati ključnu ulogu u društvenoj otpornosti, posebno tijekom razdoblja kriza (Kelly, 2006.; Hooper-Greenhill i sur., 2010.; Fujiwara, 2013.) Muzeji zajednicama 
služe kao istraživački i obrazovni centri, ukazujući na prošlost i sadašnjost materijalne i nematerijalne baštine, ali također pridonose identitetu i koheziji zajednice, posebno u vremenima neizvjesnosti poput globalne pandemije bolesti COVID-19, koja označava zdravstvenu, kao i socijalnu krizu (ICOM, 2020.). Prema pojedinim autorima, mogućnost internetskog pristupa muzejskim aktivnostima tijekom razdoblja pandemijske krize mogla bi smanjiti izolaciju, poboljšati mentalno zdravlje i podržati obrazovne i kreativne potrebe različite publike (Samaroudi i sur., 2020.).

\section{Pregled dosadašnjih istraživanja o internetskim aktivnostima muzeja tijekom pandemije bolesti COVID-19}

Muzejski sektor u cijelom svijetu vrlo je brzo reagirao na pandemijsku krizu razvijanjem internetskog sadržaja pomoću kojeg će ostati u kontaktu s publikom. To je podrazumijevalo kreativno sagledavanje muzejskih mogućnosti, razvijanje tehnoloških znanja $\mathrm{i}$ iskustava u kreiranju novih sadržaja ili prilagodbi postojećih i njihovo plasiranje preko interneta. Takva nastojanja muzeja nisu novost, a različita istraživanja uloge novih informacijsko-komunikacijskih tehnologija, posebno društvenih mreža, u poboljšanju funkcija muzejskih ustanova, posebno vezano uz njihovu obrazovnu i komunikacijsku ulogu, intenzivno se javljaju zadnjih desetak godina (Russo i sur. 2009.; Simon, 2010.; Gonzales, 2017.).

Velika istraživanja koja su provele međunarodne organizacije UNESCO, NEMO i ICOM, a u kojima su muzeji i baštinske institucije izravno upitane o njihovoj digitalnoj ponudi tijekom pandemije, pružaju određeni kontekst za razumijevanje internetskih praksi muzeja analiziranih u našem radu.

Prema istraživanju koje je proveo ICOM (2020.), uz nove oblike iskorištavanja već postojećeg digitaliziranog materijala, mnoge su muzejske institucije izvijestile da su planirane i otkazane fizičke programe i događaje prenijele u digitalnu sferu. Također, povećale su svoju digitalnu ponudu sadržajem na društvenim mrežama (46\%), pokrenule kvizove, natjecanja i izazove (19\%), organizirale i prenosile događanja uživo (19\%), uspostavile virtualne zbirke (18\%) i internetske izložbe (16\%) te izdavale publikacije (13\%) i podcaste (10\%). Inicijative koje su uglavnom provedene na početku zatvaranja bile su internetska događanja uživo (12\%) i internetske izložbe (11\%).

Prema NEMO-u (2020)., čak je 93\% ispitanih muzeja u Europi povećalo, pokrenulo ili preusmjerilo resurse u smjeru razvoja barem jednog internetskog servisa tijekom pandemije. Najveća povećanja zabilježena su vezano uz objave na društvenim mrežama (za 67\%) i videosadržaje (za 39\%), dok su među novim uslugama najčešće virtualne ture kroz muzeje (29\%) i internetski programi učenja (27\%). Povećanje digitalne ponude izravno je povezano i sa zabilježenim porastom internetskih posjeta kod većine muzeja, pri čemu su ispitani muzeji izvijestili da su među publikom najpopularniji 
društveni mediji, obrazovni materijali, videozapisi i filmovi te sadržaji povezani sa zbirkama. Porast digitalnih usluga i sadržaja koje su muzeji ponudili često je postignut traženjem od osoblja da preuzme nove odgovornosti. Izvještaj NEMO-a stoga završava naglašavanjem snažne potrebe muzeja za daljnjim ulaganjem u digitalne usluge, infrastrukturu i stjecanje digitalnih vještina zaposlenika radi razvijanja njihove ponude tijekom i nakon razdoblja pandemije.

Pandemija je ukazala i na velike nejednakosti među muzejima u svijetu u smislu napretka digitalizacije. Dok neki muzeji još nisu ni sastavili popise svojih zbirki, drugi (kojih je manje) imaju velike timove posvećene isključivo razvoju digitalnih strategija svojih institucija. Oni najveći po broju posjetitelja, koji su već ranije uložili velika sredstva u digitalizaciju svojih zbirki i razvoj društvenih mreža, tako su zabilježili značajan porast broja korisnika svojih mrežnih stranica tijekom razdoblja pandemije. $\mathrm{Na}$ primjer, muzej Louvre zabilježio je deset puta veći broj posjeta svojoj mrežnoj stranici (i do 400000 posjeta dnevno) zahvaljujući ponudi virtualnih tura i drugih internetskih aktivnosti u prvim tjednima pandemije (Brown, 2020.).

Mnogi istraživači u Europi i svijetu već su se bavili utjecajem koronavirusa na muzeje i posebno načinima na koje su se muzeji prilagodili i pokazali otpornost na krizu razvojem digitalnih mogućnosti i internetskih sadržaja. Većina autora radila je studije na nivou pojedine zemlje, te tako postoje istraživanja internetskih aktivnosti muzeja tijekom pandemije koronavirusa u Italiji (Agostino i sur., 2020.), Španjolskoj (Rivero i sur., 2020.), Norveškoj (Burke i sur., 2020.), Ujedinjenom Kraljevstvu (Kist, 2020.) i SAD-u (Samaroudi i sur., 2020.).

Rezultati navedenih istraživanja pokazuju da su muzeji u svim promatranim zemljama iznimno brzo reagirali na zatvaranje fizičkih prostora povećavajući aktivnosti na mrežnim stranicama i društvenim mrežama. Opisane su brojne aktivnosti muzeja, koje su se temeljile kako na ulaganjima prije pojave bolesti COVID-19 (digitalizacija zbirki, stvaranje virtualnih muzeja), a koja su se intenzivno koristila tijekom zatvaranja, tako i na specifičnim aktivnostima provedenima tijekom tog određenog razdoblja.

U Hrvatskoj takve analize internetskih aktivnosti hrvatskih muzeja tijekom pandemije još nisu rađene. Iznimka je tek najavljeni izvještaj Muzejskog dokumentacijskog centra, koji će analizirati mrežnu posjećenost hrvatskih muzeja tijekom pandemije (MDC, 2021.b). Prvi objavljeni podaci iz te analize, izrađene na temelju anketiranja hrvatskih muzeja, prikazuju brojeve posjeta njihovim mrežnim stranicama i profilima društvenih mreža, no ne uspoređuju ih s podacima iz prethodnih godina niti analiziraju brojnost i tipologiju internetskih sadržaja. Bez obzira na to, podaci koje je prikupio MDC važni su jer prikazuju vrlo velik broj pregleda i reakcija publike na internetske sadržaje muzeja, dok s druge strane ukazuju na nedostatak i neujednačenost podataka koje prikupljaju muzeji, a koji bi omogućili detaljniju analizu i usporedbe. 


\section{Metodologija}

Cilj ovoga rada bio je istražiti način na koji su hrvatski muzeji koristili informacijsko-komunikacijsku tehnologiju tijekom pandemije koronavirusa kako bi nastavili s aktivnostima. U tom kontekstu, postavili smo tri istraživačka pitanja:

- Koliko je hrvatskih muzeja poduzelo neki oblik internetske aktivnosti tijekom krize uzrokovane bolešću COVID-19?

- Koje su vrste internetskih aktivnosti bile poduzete u smislu njihovog formata, korištene tehnologije i ciljane publike?

- Koliko se povećao odaziv publike na internetske aktivnosti hrvatskih muzeja tijekom pandemije u odnosu na prethodno razdoblje?

U tu svrhu, proveli smo analizu sadržaja mrežnih stranica i društvenih mreža hrvatskih muzeja. Istraživani uzorak uključivao je 162 muzeja upisana u Upisnik javnih i privatnih muzeja u Republici Hrvatskoj. Prikupljeni su i analizirani podaci o digitalnim resursima koje su muzeji ponudili u godini dana od ožujka 2020. do ožujka 2021. godine, a koji se odnose na njihovu količinu, vrstu, format, ciljanu publiku te doseg.

\section{Rezultati istraživanja}

\subsection{Klasifikacija digitalnih aktivnosti hrvatskih muzeja tijekom pandemije bolesti COVID-19}

Tablica 1.

Vrste digitalnih aktivnosti muzeja u Republici Hrvatskoj

\begin{tabular}{|l|c|l|}
\hline $\begin{array}{l}\text { Vrsta digitalne } \\
\text { aktivnosti muzeja }\end{array}$ & $\begin{array}{c}\text { Ukupan broj } \\
\text { muzeja koji nude } \\
\text { ovu aktivnost }\end{array}$ & \multicolumn{1}{|c|}{ Primjeri } \\
\hline Virtualne izložbe & 15 & $\begin{array}{l}\text { Arheološki muzej Narona, Muzej Mimara, Muzej Croata insulanus } \\
\text { Grada Preloga, Muzej Brdovec, Muzej antičkog stakla u Zadru, } \\
\text { Muzej betinske drvene brodogradnje }\end{array}$ \\
\hline Virtualne šetnje & 15 & $\begin{array}{l}\text { Samoborski muzej, Muzeji Hrvatskog zagorja, Muzej Sinjske alke, } \\
\text { Gradski muzej Varaždin }\end{array}$ \\
\hline Virtualne šetnje 3D & 11 & $\begin{array}{l}\text { Muzej vučedolske kulture, Muzej za umjetnost i obrt, Muzej } \\
\text { krapinskih neandertalaca, Muzej Apoksiomena, Muzej Slavonije }\end{array}$ \\
\hline $\begin{array}{l}\text { Edukacijske aktivnosti } \\
\text { za djecu i odrasle }\end{array}$ & $\begin{array}{l}\text { Arheološki muzej u Zagrebu, Tehnički muzej Nikola Tesla, } \\
\text { Etnografski muzej u Zagrebu, Arheološki muzej Istre, Hrvatski } \\
\text { povijesni muzej }\end{array}$ \\
\hline $\begin{array}{l}\text { Edukacijske aktivnosti } \\
\text { za djecu }\end{array}$ & 11 & $\begin{array}{l}\text { Dubrovački muzeji i galerije, Arheološki muzej Istre, Gradski muzej } \\
\text { Vinkovci, Muzej suvremene umjetnosti, Arheološki muzej Zagreb }\end{array}$ \\
\hline
\end{tabular}




\begin{tabular}{|c|c|c|}
\hline $\begin{array}{l}\text { Vrsta digitalne } \\
\text { aktivnosti muzeja }\end{array}$ & $\begin{array}{l}\text { Ukupan broj } \\
\text { muzeja koji nude } \\
\text { ovu aktivnost }\end{array}$ & Primjeri \\
\hline $\begin{array}{l}\text { Edukacijske aktivnosti } \\
\text { za odrasle }\end{array}$ & 3 & $\begin{array}{l}\text { Arheološki muzej Istrem, Muzej suvremene umjetnosti, Muzej } \\
\text { vučedolske kulture }\end{array}$ \\
\hline $\begin{array}{l}\text { Specijalne aktivnosti na } \\
\text { društvenim mrežama }\end{array}$ & 4 & $\begin{array}{l}\text { Gradski muzej Sisak, Muzej likovnih umjetnosti, Muzej vučedolske } \\
\text { kulture, Dubrovački muzeji }\end{array}$ \\
\hline YouTube kanal & 20 & $\begin{array}{l}\text { Gradski muzej Križevci, Arheološki muzej Istre, Muzej Belišće, } \\
\text { Hrvatski školski muzej, Muzej Slavonije, Pomorski i povijesni muzej } \\
\text { Hrvatskog primorja, Muzej Međimurja Čakovec }\end{array}$ \\
\hline Mobilne aplikacije & 5 & $\begin{array}{l}\text { Muzej triljskog kraja, Gradski muzej Požega, Zavičajni muzej } \\
\text { Stjepan Gruber u Županji, Arheološki muzej Zagreb, Muzej } \\
\text { Moslavine }\end{array}$ \\
\hline Internetske publikacije & 6 & $\begin{array}{l}\text { Muzej grada Trogira, Pomorski i povijesni muzej Hrvatskog } \\
\text { primorja Rijeka, Muzej antičkog stakla u Zadru, Hrvatski muzej } \\
\text { naivne umjetnosti, Muzej Prigorja }\end{array}$ \\
\hline Blog & 4 & $\begin{array}{l}\text { Muzeji i galerije Konavala, Muzej Mimara, Muzej grada Trogira, } \\
\text { Gradski muzej Karlovac }\end{array}$ \\
\hline Nagradne igre & 1 & Arheološki muzej Osijek \\
\hline Internetski koncert & 1 & Muzej suvremene umjetnosti Istre \\
\hline Audiovodič & 3 & Zavičajni muzej Ogulin, Muzeji i galerije Konavala, Muzej Mimara \\
\hline Internetsko otvaranje & 4 & $\begin{array}{l}\text { Arheološki muzej u Zagrebu, Etnografski muzej u Zagrebu, Muzej } \\
\text { Grada Rovinja, Pomorski i povijesni muzej Hrvatskog primorja } \\
\text { Rijeka }\end{array}$ \\
\hline
\end{tabular}

Od 162 promatrana muzeja, njih 126 ponudilo je neki oblik internetskog sadržaja tijekom razdoblja pandemije, što je ukupno 77,8\% muzeja. Tablica 1 prikazuje klasifikaciju tih aktivnosti u 15 tipova: virtualne izložbe, virtualne šetnje, virtualne šetnje 3D, edukacijske aktivnosti za djecu i odrasle, edukacijske aktivnosti za djecu, edukacijske aktivnosti za odrasle, specijalne aktivnosti na društvenim mrežama, Youtube kanal, mobilne aplikacije, internetske publikacije, blog, nagradne igre, internetski koncert, audiovodič te internetsko otvaranje.

Kao što je vidljivo u tablici 1 , najviše muzeja u Republici Hrvatskoj tijekom razdoblja pandemije ponudilo je svojim korisnicima virtualne izložbe $(32 \%)$, pri čemu su najzastupljenije one koje se sastoje od fotografija izložaka s opisom. Među tim muzejima ističe se Arheološki muzej Narona, koji svoju kolekciju Augusteum nudi s mogućnosti 
detaljnog pregleda, uz tekst opisa te rotaciju izloška. Valja istaknuti i Muzej Croata insulanus Grada Preloga, koji nudi popis djela, virtualnu izložbu 3D s mogućnošću korištenja tipki za kretanje, približavanje predmeta, izgled 3D makete, vrlo detaljno i $s$ brojnim mogućnostima.

Virtualne šetnje kroz muzej nudi ukupno 15 od promatranih muzeja, a kao pozitivan primjer ističe se Samoborski muzej. Iako rezolucija nije na zavidnom nivou, muzej nudi virtualni obilazak, gdje je osim panoramskog pregleda u 360 stupnjeva doživljaj virtualne stvarnosti upotpunjen interaktivnim elementima koji otkrivaju dodatne zanimljivosti kroz fotografije, tekst, video i audiosadržaj.

Virtualne šetnje 3D kroz muzej nudi ukupno 15 muzeja, a kao primjer autorice ističu Muzej triljskog kraja, koji kroz prikaz u 360 stupnjeva predstavlja suvremenu, inovativnu i interaktivnu prezentaciju muzejskog postava koristeći najnoviju tehnologiju virtualne stvarnosti ili pak Muzej za umjetnost i obrt, koji nudi 3D šetnju kroz muzej $s$ mogućnošću mjerenja muzejskih predmeta.

U Republici Hrvatskoj edukacijske i animacijske aktivnosti u muzejima posljednjih godina bilježe rast. Tradicionalno gledana uloga muzeja kao formalne kulturne institucije u kojoj se samo posjećuju izložbe polako se napušta, te muzej preuzima novu ulogu u kojoj, pored svoje redovne muzejske djelatnosti, postaje mjesto susreta i različitih animacijskih aktivnosti za djecu i odrasle. Tijekom razdoblja pandemije 11 je muzeja nudilo svojim korisnicima edukacijske aktivnosti za djecu i odrasle. Neke od zanimljivih aktivnosti koje je nudio Arheološki muzej u Zagrebu svojim korisnicima su: kvizovi, ciklus radionica za odrasle pod nazivom Prehistory adventure, „Muzej iza kulisa - škola u muzeju“ za starije od 15 godina, s ciljem popularizacije muzejskog rada, te slagalica o bakrenom dobu za one najmlađe korisnike. Muzej suvremene umjetnosti svojim je korisnicima nudio zanimljive knjige koje se mogu prolistati na internetu te projekte i virtualne videoigrice poput „Avanture Vita i Nade“, putem koje se mlađa publika (ali i ona starija) može na interaktivan način upoznati s jednom od njihovih zbirki i umjetničkim radovima Vjenceslava Richtera. Pokrenuli su i nove edukativne programe poput ciklusa „MSU priručnik za početnike“, gdje se u kratkoj formi i na

Tehnički muzej Nikola Tesla nudio je predavanja i radionice putem društvene mreže Facebook i svog YouTube kanala, Arheološki muzej Istre započeo je s edukativnim sadržajem za najmlađe te s edukativnim programom na društvenim mrežama (Facebook, Twitter, Instagram) pod nazivom „Virtualne pedagoške aktivnosti: $\mathrm{O}$ životinjama i 
ljudima“. Muzej Prigorja nudio je internetsko učenje i zabavu kroz društvenu igru „Pamtilica“ za vježbanje pamćenja, namijenjenu djeci i odraslima. Hrvatski povijesni muzej pozivao je virtualne posjetitelje da se putem Facebooka uključe u virtualni muzejski svijet te da na zabavan način krenu u potragu za sedam hrvatskih velikana.

Rezultati provedenog istraživanja pokazuju kako muzeji u Republici Hrvatskoj sve više pažnje pridaju svojim najmlađim korisnicima. Pa je tako, osim prethodno spomenutih aktivnosti muzeja za djecu i odrasle, 11 muzeja imalo specifične aktivnosti za djecu. Gradski muzej Vinkovci nudio je edukativne igre namijenjene djeci, poput kartica memorije o arheologiji grada Vinkovaca te etnološku varijantu kviza „Tko želi biti milijunaš“. Drugi dobar primjer Arheološki je muzej Zagreb, koji je pripremio virtualno izdanje izložbenog postava u kojem djeca i mladi kroz igru i zabavu, slažući slagalice, mogu naučiti nešto o Slavenima i Avarima.

Digitalne aktivnosti muzeja koje uključuju specijalne aktivnosti na društvenim mrežama u ovom radu podrazumijevaju participativnost muzeja s korisnicima. One se ogledaju u projektnim aktivnostima muzeja u koje su pozvali svoje korisnike da se uključe. Tako su Dubrovački muzeji pokrenuli projekt \#karantenadubrovnik2020s ciljem dokumentiranja života stanovnika Dubrovnika i okolice u jedinstvenim okolnostima izolacije i karantene uzrokovanih pandemijom bolesti COVID-19, te su pozvali korisnike da šalju svoje fotografije, koje će muzej objavljivati na društvenim i mrežnim stranicama. Na sličan se način i Gradski muzej Sisak okrenuo svojim korisnicima te je pokrenuo akciju prikupljanja motiva Siska sa starih razglednica i fotografija te ih objavljivao putem društvenih mreža.

Premda je YouTube besplatan medij i postaje vrlo važno sredstvo promoviranja, u promatranom razdoblju aktivnost na YouTube kanalu zabilježena je samo kod 20 muzeja. Aktivnost se uglavnom odnosi na snimke virtualnih vodstava kroz postav, kratke audiovizualne zapise zanimljivosti vezanih uz djelatnost muzeja ili muzejski izložak. Kao dobre primjere autorice izdvajaju Etnografski muzej u Zagrebu, koji je pokrenuo projekt „Muzej s kauča“, koji obuhvaća ciklus pripovjedaonica, predstavljanje internetske zbirke te predstavljanje predmeta uz koje se vezuju zanimljive priče o njihovu nastanku, upotrebi i ljudima koji su ih izradili ili koristili. Slično radi i Muzej grada Pregrade na svom YouTube kanalu, gdje objavljuje kazivanja sudionika muzejskog edukativnog programa o zagorskim običajima.

Neosporno je da u današnjem poslovanju većoj efikasnosti i efektivnosti doprinose digitalne tehnologije i društvene mreže, koje su danas postale neizostavan oblik komuniciranja s javnostima. Stoga i ne čudi sve prisutniji trend postavljanja mobilnih aplikacija u institucije kulture. U promatranom razdoblju rezultati istraživanja pokazali su kako svega pet muzeja ima vlastitu mobilnu aplikaciju. Gradski muzej Požega u studenom 2020. godine predstavio je mobilnu aplikaciju pod nazivom „Blago Požege“, koja predstavlja edukativnu muzejsku potragu čiji je cilj korisnicima pruži- 
ti mogućnost samostalnog istraživanja grada, upoznavanje baštine Požege i muzeja. Muzej triljskog kraja ima mobilnu aplikaciju pod nazivom „3D-3LJ“, koja korisnicima nudi edukativne i interaktivne sadržaje poput informacija o povijesti arheoloških istraživanja i lokaliteta Tilurij, istraženoj logorskoj arhitekturi, pokretnim nalazima i muzejskim eksponatima te sadrži interaktivnu edukativnu igru za najmlađe korisnike. Zavičajni muzej Stjepan Gruber u Županji ima naprednu multimedijalnu aplikaciju, koja korisnicima, osim što je virtualni vodič kroz muzej, omogućava i vrlo atraktivno i interaktivno virtualno iskustvo. Arheološki muzej u Zagrebu ima mobilnu aplikaciju s edukacijskim i zabavnim sadržajem pod nazivom Iron Age Danube.

U promatranom razdoblju internetsku publikaciju objavilo je šest muzeja, a jedan od primjera jest Muzej Prigorja, čija e-publikacija „Pozdrav iz Sesveta“ pomaže čitateljima rekonstruirati tijek negdašnjeg života uz pomoć starih razglednica i dopisnica kao i putem zanimljivih priča iz života u Sesvetama i obližnjim prigorskim naseljima. Blog su aktivno vodila četiri muzeja, a to su prema istraživanju: Muzeji i galerije Konavala, Muzej Mimara, Muzej grada Trogira te Gradski muzej Karlovac. Nagradnu igru za korisnike i širu publiku organizirao je Arheološki muzej Osijek, a Muzej suvremene umjetnosti Istre organizirao je internetski koncert.

Zbog epidemioloških mjera koje su bile na snazi brojna otvorenja izložbi u muzejima bila su organizirana u strogo kontroliranim uvjetima i s ograničenim brojem posjetitelja, stoga su neki muzeji našli način kako svojim korisnicima omogućiti prisustvo na otvorenju. Tome su, naravno, doprinijele ranije spomenute digitalne tehnologije i društvene mreže, pa je tako Arheološki muzej u Zagrebu internetsko otvorenje održao putem aplikacije Zoom, Etnografski muzej u Zagrebu imao je prijenos uživo putem društvene mreže Facebook kao i muzej Grada Rovinja, dok je Pomorski i povijesni muzej Hrvatskog primorja Rijeka otvorenje izložbe prenosio putem platforme za razmjenu videozapisa Vimeo.

\subsection{Analiza Facebook stranica odabranih hrvatskih muzeja - pratitelji, objave i reakcije}

Današnje suvremeno poslovanje i komunikacija kulturnih institucija $s$ javnostima nezamislivi su bez upotrebe novih medija i društvenih mreža. Društvene mreže omogućavaju kulturnim institucijama održavanje komunikacije s postojećim korisnicima, ali isto tako doprinose i privlačenju novih. Važnost i uloga društvenih mreža posebno je vidljiva u vrijeme pandemije uzrokovane koronavirusom, gdje se zbog novonastale situacije redovan rad i program muzeja počeo odvijati u virtualnom svijetu. Facebook je najčešće upotrebljavana i najzastupljenija društvena mreža u Republici Hrvatskoj budući da ima najveći broj aktivnih korisnika, stoga ne čudi da upravo ona predstavlja glavnu društvenu mrežu za informiranje korisnika mnogih muzeja, koja pri tome pruža mogućnost dvosmjerne komunikacije. 
U tablici 2 prikazani su rezultati desk-istraživanja Facebook stranica svih muzeja u Republici Hrvatskoj. Prvi parametar bio je broj sljedbenika u drugom tjednu ožujka 2021. godine, na temelju čega su dobiveni podaci o tome kojih je 15 muzeja u promatranom razdoblju imalo najveći broj sljedbenika. U analizi objave muzeja razvidno je da su gotovo svi muzeji objavljivali informacije o aktivnostima i informacijama vezanima za muzejsku građu. Tek njih nekoliko objavljivalo je informacije i zanimljivosti koje nisu vezane uz njihov redoviti program rada i njihovu muzejsku građu, a objava koje pozivaju na interakciju gotovo da i nema.

Tablica 2.

Analiza Facebook stranice muzeja: pratitelji, objave i reakcije korisnika

\begin{tabular}{|c|c|c|c|c|c|c|}
\hline & TOP 15 MUZEJA NA FACEBOOKU & 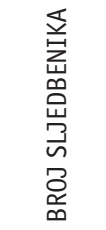 & 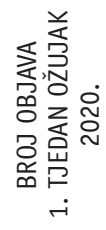 & 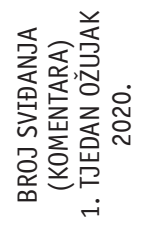 & 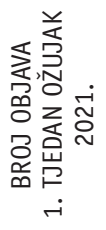 & 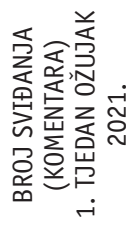 \\
\hline 1. & $\begin{array}{l}\text { TEHNIČKI MUZEJ NIKOLA } \\
\text { TESLA }\end{array}$ & 27863 & 6 & $876(25)$ & 7 & $344(0)$ \\
\hline 2. & MUZEJ MIMARA & 21109 & 4 & $78(1)$ & 1 & $25(0)$ \\
\hline 3. & $\begin{array}{l}\text { MUZEJ SUVREMENE } \\
\text { UMJETNOSTI }\end{array}$ & 19996 & 8 & $122(2)$ & 12 & $149(1)$ \\
\hline 4. & MUZEJ ZA UMJETNOST I OBRT & 15620 & 14 & $342(4)$ & 8 & $78(1)$ \\
\hline 5. & $\begin{array}{l}\text { ARHEOLOŠKI MUZEJ U } \\
\text { ZAGREBU }\end{array}$ & 15457 & 4 & $263(0)$ & 0 & 0 \\
\hline 6. & MUZEJ DVOR TRAKOŠĆAN & 10170 & 0 & 0 & 1 & $50(0)$ \\
\hline 7. & MUZEJ GRADA ZAGREBA & 8931 & 2 & $80(2)$ & 5 & $86(0)$ \\
\hline 8. & ETNOGRAFSKI MUZEJ ZAGREB & 8603 & 6 & $407(6)$ & 5 & $281(26)$ \\
\hline 9. & MUZEJ VUČEDOLSKE KULTURE & 7321 & 6 & $315(0)$ & 5 & $219(4)$ \\
\hline 10. & $\begin{array}{l}\text { MUZEJ I MEMORIJALNI CENTAR } \\
\text { DRAŽENA PETROVIĆA }\end{array}$ & 7219 & 0 & 0 & 2 & $305(11)$ \\
\hline 11. & MUZEJ GRADA RIJEKE & 7059 & 1 & $124(4)$ & 1 & $119(5)$ \\
\hline 12. & DUBROVAČKI MUZEJI & 6672 & 1 & $224(54)$ & 8 & $199(7)$ \\
\hline 13. & $\begin{array}{l}\text { HRVATSKI PRIRODOSLOVNI } \\
\text { MIUZEJ }\end{array}$ & 6288 & 1 & $59(0)$ & 1 & $50(0)$ \\
\hline 14. & ARHEOLOŠKI MUZEJ ISTRE & 5583 & 2 & $206(5)$ & 8 & $148(2)$ \\
\hline 15. & PRIRODOSLOVNI MUZEJ ISTRE & 4691 & 7 & $76(1)$ & 10 & $68(0)$ \\
\hline & UKUPNO & 152353 & 62 & $3172(104)$ & 74 & $2121(57)$ \\
\hline
\end{tabular}


Nakon definiranja 15 muzeja u Republici Hrvatskoj koji imaju najviše pratitelja u promatranom razdoblju, analizirali smo broj objava u prvom tjednu 2020. godine i te rezultate usporedili s objavama godinu dana kasnije, odnosno u prvom tjednu ožujka 2021. godine. Iz tablice 2 vidljivo je da je Muzej za umjetnost i obrt imao najviše objava u prvom tjednu ožujka 2020. godine, i to njih 14, dok Muzej i memorijalni centar Dražena Petrovića i muzej Dvor Trakošćan nisu imali ni jednu objavu. Pri vrhu su po broju tjednih objava i Muzej suvremene umjetnosti (8), Prirodoslovni muzej Istre (7), Tehnički muzej Nikola Tesla (6), Etnografski muzej Zagreb (6) i Muzej vučedolske kulture (6), što bi značilo da su u prosjeku imali jednu objavu dnevno, osim na dane kada muzej nije radio.

Podaci o objavama ostalih muzeja navedenih u tablici 2 koji su u promatranom tjednu imali jednu ili dvije objave tjedno pokazuju kako njihove digitalne aktivnosti, bez obzira na broj pratitelja na društvenim mrežama, nisu porasle.

Broj reakcija na objave i broj korisničkih komentara na njih proporcionalan je ukupnom broju sljedbenika. Najviše reakcija na objave u promatranom razdoblju imale su objave Tehničkog muzeja Nikola Tesla (876), zatim slijede Etnografski muzej Zagreb (407), Muzej za umjetnost i obrt (342) te Muzej vučedolske kulture (315). Kada navedene aktivnosti korisnika spomenutih muzeja usporedimo s ostavljenim komentarima, tada dolazimo do zaključka kako je jedino Tehnički muzej Nikola Tesla ostvario dodatnu interakciju s korisnicima. Zanimljivo je kako su Dubrovački muzeji sa samo jednom objavom u navedenom tjednu ostvarili najveći broj komentara od korisnika (54), a radi se o informativnoj objavi o napredovanju zaposlenica muzeja.

Analizirajući Facebook stranicu odabranih muzeja godinu dana kasnije, pod istim parametrima, dolazimo do zaključka kako bitnih pomaka sa strane sljedbenika nema, odnosno nije došlo do povećanja interakcije s korisnicima. Iako je u tablici 2 vidljivo da je broj tjednih objava u prvom tjednu ožujka 2021. godine porastao, broj reakcija na objave u padu je za $35 \%$, a broj komentara ostavljenih od korisnika također bilježi pad od $55 \%$. godini te su muzeji korištenjem digitalnih medija prilagodili svoje usluge i sadržaje novim uvjetima poslovanja, što je primijećeno i kroz analizu sadržaja odabranih Facebook stranica muzeja u razdoblju od 2. ožujka 2020. do 7. ožujka 2021. godine, to ipak nije rezultiralo povećanjem interakcije s korisnicima. 


\section{Zaključak}

Privremena zatvaranja i smanjeni posjeti muzejima, koji kao posljedica krize uzrokovane pandemijom bolesti COVID-19 traju već više od godinu dana, neosporno će imati ozbiljne ekonomske i socijalne posljedice koje bi dugoročno mogle utjecati na muzeje.

Istraživanja rađena na svjetskoj i nacionalnim razinama o reakcijama muzeja na krizu pokazala su da su muzeji odgovorili na potrebe korisnika nuđenjem različitih internetskih aktivnosti i resursa kao što su obrazovni materijali, virtualne šetnje, događanja uživo i kreativni sadržaji, od kojih su mnogi bili vrlo učinkoviti u smislu odaziva publike. Internetske aktivnosti možda neće nadoknaditi novčane gubitke, ali omogućile su zadržavanje kontakta s korisnicima i nastavak znanstvenih, obrazovnih i komunikacijskih aktivnosti.

Istraživanje provedeno za potrebe ovog rada pokazuje da ni hrvatski muzeji nisu zaostajali u nuđenju raznolikog internetskog sadržaja tijekom razdoblja pandemije. Od 162 hrvatska muzeja njih 126 (77,8\%) nudilo je neki oblik digitalnog sadržaja. Provedena analiza mrežnih stranica i društvenih mreža hrvatskih muzeja rezultirala je klasifikacijom internetskih aktivnosti u 15 vrsta, od kojih su najzastupljenije bile virtualne izložbe. Međutim, bogata ponuda ne znači nužno i povećanje angažmana publike, kao što je pokazala analiza Facebook stranica najposjećenijih hrvatskih muzeja.

Povećanje aktivnosti hrvatskih muzeja na društvenim mrežama, kreativne digitalne inicijative i različite nove obrazovne i komunikacijske strategije ukazuju na činjenicu da je pandemijska kriza značajno ubrzala njihovu digitalnu evoluciju te da bi posljedice aktualne digitalne transformacije mogle biti dugoročne i utjecati na budući razvoj poslovanja i usluga. Procesi intenzivnije digitalizacije hrvatskih muzeja i osnaživanja komunikacije s korisnicima preko društvenih mreža započeli su prije nešto više od deset godina. Pandemija je te procese samo ubrzala, intenzivirala i dodatno promovirala u javnosti. Pokazala je da muzeji trebaju biti spremniji na krizne situacije te dodatno poraditi na svojoj mrežnoj prisutnosti nudeći dobro promišljen, funkcionalan i interaktivan sadržaj. Ono što se, stoga, predviđa u budućnosti nova su ulaganja u digitalnu infrastrukturu i digitalne programe te, posljedično, povećana potreba za dodatnim digitalnim opismenjavanjem zaposlenika. Sve to predstavlja ogroman izazov s kojim će se muzeji morati suočiti ako žele i dalje ostati relevantni na poljima obrazovanja, širenja kulture, promicanja društvene kohezije te jačanja lokalne i regionalne kreativne ekonomije u budućnosti. 


\section{Literatura}

1. Agostino, D.; Arnaboldi, M. and Lampis, A. (2020). Italian state museums during the COVID-19 crisis: from onsite closure to online openness. Museum Management and Curatorship, 35 (4): 362-372.

2. Brown, S. (2020). Hoćete u muzej? Pođite odmah!. Panorama DW. https:// www.dw.com/hr/hoćete-u-muzej-pođite-odmah/a-53117650. (Pregledano 2. veljače 2021.)

3. Burke, V; Jørgensen, D. and Jørgensen F. A. (2020.) Museums at Home: Digital Initiatives in Response to COVID-19. Norsk museumstidsskrift, (6)2-2020: 117-123.

4. ICOM Međunarodno vijeće muzeja (2020). Museums, museum professionals and COVID-19. https://icom.museum/wp-content/uploads/2020/05/ReportMuseums-and-COVID-19.pdf. (Pregledano 3. travnja 2021.)

5. Fujiwara, D. (2013). Museums and happiness: the value of participating in museums and the arts. Report for the Happy Museum Project. Arts Council England. http://www.happymuseumproject.org/wpcontent/uploads/2013/04/Museums and happiness DFujiwara April2013.pdf. (Pregledano 15. veljače 2021.)

6. Gonzales, R. (2017). Keep the Conversation Going: How Museums Use Social Media to Engage the Public. The Museum Scholar, 1 (1). https://articles.themuseumscholar.org/2017/02/06/vollno1gonzalezl. (Pregledano 15. veljače 2021.)

7. Hooper-Greenhill, E.; Phillips, M. and Woodham, A. (2009). Museums, schools and geographies of cultural value. Cultural Trends, 18 (2): 149-183.

8. Kelly, L. (2006). Measuring the impact of museums on their community. The role of the 21st century museum, INTERCOM Conference paper. http://www.intercom.museum/documents/1-2Kelly.pdf. (Pregledano 15.2.2021.)

9. Kist, C. (2020). Museums, Challenging Heritage and Social Media During COVID-19. Museum \& Society, 18(3): 345-348.

10. Muzejski dokumentacijski centar (MDC) (2021a). Posjećenost hrvatskih muzeja u 2020. izgubili četiri milijuna posjetitelja. Newsletter, broj 134, 9. 2.2021. https:// mdc.hr/hr/mdc/publikacije/newsletter/newsletter-9-2-2021\#posjecenost-2020. (Pregledano 3. travnja 2021.)

11. Muzejski dokumentacijski centar (MDC) (2021b). Virtualna 2020 - prvi podaci o online posjećenosti hrvatskih muzeja. Newsletter, broj 135, 23. 2. 2021. https:// $\mathrm{mdc} . \mathrm{hr} / \mathrm{hr} / \mathrm{mdc} / \mathrm{publikacije/newsletter/newsletter-23-2-2021/}$. (Pregledano 3. travnja 2021.)

12. Network of European Museum Organisations (NEMO) (2020). Survey on the Impact of the COVID-19. Situation on Museums in Europe. Findings and Recommendations. https://www.ne-mo.org/advocacy/our-advocacy-work/museumsduring-covid-19.html. (Pregledano 3. travnja 2021.)

13. Rivero, P.; Navarro-Neri, I.; García-Ceballos, S. and Aso, B. (2020). Spanish Archaeological Museums during COVID-19 (2020): An Edu-Communicative Analysis of their Activity on Twitter through the Sustainable Development Goals. Sustainability, 12 (19), 8224. 
14. Russo, A.; Watkins, J. and Groundwater-Smith, S. (2009). The impact of social media on informal learning in museums. Educational Media International, 46 (2): 153-166.

15. Samaroudi, M.; Rodriguez Echavarria, K and Perry, L (2020). Heritage in lockdown: digital provision of memory institutions in the UK and US of America during the COVID-19 pandemic. Museum Management and Curatorship, 35 (4): 337-361.

16. Simon, N. (2010). The participatory museum. Santa Cruz: Museum 2.0. http:// www.participatorymuseum.org/read/. (Pregledano 2.veljače. 2021.)

17. UNESCO (2020). Report on Museums Around the World in the Face of COVID-19. Paris: UNESCO. https://en.unesco.org/news/launch-unesco-report-museumsaround-world-face-covid-19. (Pregledano 3. travnja 2021.) 


\title{
Museums from Home: Digital Activities of Croatian Museums during the COVID-19 Disease Pandemic
}

\author{
Lana Domšić \\ University of Applied Sciences Baltazar Zaprešić, Croatia \\ e-mail: ldomsic@bak.hr \\ Barbara Franić \\ University of Applied Sciences Baltazar Zaprešić, Croatia \\ e-mail:bfranic@bak.hr \\ Mirna Perić \\ University of Applied Sciences Baltazar Zaprešić, Croatia \\ e-mail: pericmirna1@gmail.com
}

\begin{abstract}
In March 2020, Croatian museums closed their doors for several weeks to prevent the spread of COVID-19. The period of physical confinement was further extended for some Zagreb museums that were severely damaged in the earthquake. After opening, as in many other museums in Europe and the world, physical visits continued to decline and museums recorded a drastic drop in visitors and financial losses. In response to the current situation, with the aim of continuing to fulfil their social, cultural and educational function, museums have turned to the internet and social networks as places for dialogue with users, dissemination of content and presentation of events that couldn't be physically organized. Many museums devoted themselves to creation of online resources such as digital exhibitions, virtual tours, e-learning materials, online conferences and tried to connect with their audiences in different ways and on different platforms.
\end{abstract}

The aim of this paper was to investigate how Croatian museums have adapted their services and contents to new business conditions by using digital media. The paper analyses and evaluates the activities of museums on websites and social networks in one year period since the beginning of the pandemic. The results indicate a quantitatively as well as qualitatively rich online museums' presence that could mark the beginning of a new era in digital communication and dissemination of heritage content. The research concludes that the digitization of museum activities is necessary for the future sustainability of museum functions and encourages further reflection on the direction of digital access to culture and heritage.

Key words: virtual museums, digitization, digital technology, social networks, COVID-19, pandemic, digital transformation, users. 